\title{
Nature trails in the Atlantic Forest as a resource for teaching botany
}

\section{Trilhas na Mata Atlântica como recurso para o ensino de botânica}

\author{
${ }^{1}$ Cristiane Pimentel Victório cris.pvictor@gmail.com
}

${ }^{1}$ Luciano Tadeu

\begin{abstract}
The teaching of Botany is inserted in the context of Biological Sciences graduate courses. Among students, Botany is one of the areas with the greatest difficulty in learning. College students should be exposed to classes that treat the ecosystem as part of an integrated environmental education program. To examine this proposition, practical activities were carried out at Parque Estadual da Pedra Branca (PEPB) and at Parque Nacional da Tijuca, State Conservation Units of Rio de Janeiro, which represent part of the rich Brazilian biodiversity. More specifically, the present paper suggests that field classes along an ecological trail could be an invaluable pedagogical alternative toward increasing students' interest in Botany. Here, we considered plant biodiversity, litterfall, ecological relationships, morphological features and plant physiology and secondary metabolites. After the ecological trail walk, we applied a questionnaire to get students' impressions most of which were very favorable to the field classes as a didactic resource. Most students had the first contact with a Conservation Unit of Atlantic Forest through this practice, and learned botanical and environmental aspects in situ. Consequently, we can recommend that tracks can contribute to the teaching of Botany and to a multidisciplinary approach. Besides improving student engagement and the quality of the teaching-learning process.
\end{abstract}

Keywords: Environmental education. Ecological track. Interpretative tracks. Teaching Botany. Conservation Unit.

\section{RESUMO}

O ensino de Botânica está inserido no contexto dos cursos de graduação em Ciências Biológicas. Entre os estudantes, a Botânica é uma das áreas de maior dificuldade de aprendizagem. Os estudantes universitários devem ser expostos a aulas que tratam o ecossistema como parte de um programa integrado de educação ambiental. Para examinar essa proposta, foram realizadas atividades práticas no Parque Estadual da Pedra Branca (PEPB) e no Parque Nacional da Tijuca, Unidades Estaduais de Conservação do Rio de Janeiro, que representam uma parte da rica biodiversidade brasileira. Mais especificamente, o presente artigo sugere que as aulas de campo ao longo de uma trilha ecológica podem ser uma alternativa pedagógica inestimável para aumentar o interesse dos estudantes pela Botânica. Abordamos a biodiversidade vegetal, a serapilheira, as relações ecológicas, as características morfológicas e a fisiologia dos vegetais e os metabólitos secundários. Após a trilha, aplicamos um questionário para averiguar as impressões dos alunos. Os alunos foram favoráveis a aula de campo como recurso didático. A maioria dos alunos teve o primeiro contato com uma Unidade de Conservação de Mata Atlântica através dessa prática, e aprenderam in situ aspectos botânicos e ambientais. Consequentemente, recomendamos as trilhas como recurso que contribui para o ensino de Botânica e ainda para uma abordagem multidisciplinar. Além de favorecer o envolvimento dos alunos e a qualidade do processo de ensino-aprendizagem.

Palavras-chave: Educação ambiental. Trilha ecológica. Trilha interpretativa. Ensino de Botânica. Unidade de Conservação. 


\section{INTRODUCTION}

Plant biodiversity is an important component that defines the features of an ecosystem, along with other living organisms and a set of physically interacting ecological factors. Plants occupy the first trophic level that produces organic matter by fixing the carbon of the $\mathrm{CO}_{2}$ atmosphere by the action of the Rubisco enzyme using solar energy, thereby sustaining, as producers, the food chain within ecosystems. The value of botanical knowledge can be appreciated in medicine and therapeutics, in technological areas, including the food industry, as well as the textile industry, paper industry, biopolymers, biofuel and phytoremediation. Man's use of plants has grown in the last decades, which calls for a greater understanding of plant structure and physiological processes, as well as the greater ecosystem and its dynamics.

Processed food and synthetic medicines are commonplace, while traditional plant use has gone by the wayside. Even though plants have an important presence in modern life, students continue to resist the field of botany teaching, from elementary to undergraduate levels, and students often bring their biases, making it difficult to teach and learn. Therefore, many challenges lie ahead in the search for alternatives that will make teaching botany attractive as an academic and career choice (Salatino, Buckeridge, 2016; Ursi, Barbosa, Sano, \& Berchez, 2018).

Trails provide an insight into the connectedness of ecological communities (Carvalho, Bóçon, 2004). Also, trails provide adventure, tourism opportunites and routes for religious pilgrimages (Carvalho, Bóçon, 2004). In contemporary societies, advancing technologies have placed barriers between humans and nature; in this sense, therefore, trails become a new means of experiencing nature and even conducting research outside the lab. A planned trail experience in association with environmental interpretation can reignite interest in the otherwise lost connection between man and nature, thus sparking renewed interest in the role ecosystems play in greater environmental structures (MMA, 2006).

Education is the key means of understanding biodiversity, sustainable practices and raising public awareness. Teachers should make the classroom experience more attractive and contextualized, but learning experiences outside the regular classroom can lead to a more informed citizenery and a citizenery more conscious of the need to preserve and conserve the environment. It is from this perspective that classes held in a trail setting represent a strategy that stimulates the teaching-learning process toward promoting physical activity and more incisive perceptions of the environment and its ecosystems.

The state of Rio de Janeiro has three urban forests: Parque Estadual da Pedra Branca (PEPB), Parque Estadual do Mendanha and Parque Nacional da Tijuca, areas of the Atlantic Forest. The PEPB, located in the West Zone with 12,393.84 hectares, occupies about $10 \%$ of the City of Rio de Janeiro, encompassing the largest urban forest in the world. The Parque Estadual do Mendanha is also in the West Zone, while the Parque Nacional da Tijuca (Parna Tijuca or PNT) has its main entries in the Tijuca district, North Zone with 3,953 hectares (INEA, 2013). PEPB is the starting point of the largest Ecological Corridor in the World, the Transcarioca trail, formed by 27 Conservation Units of the State and Federal Municipal Administration, covering 30\% of the City of Rio de Janeiro and considered a significant Atlantic Forest reserve, making an important contribution toward reducing the high temperatures of the region (Firme, Vincenz, Macedo, Silva, \& Oliveira, 2001; INEA, 2013). Apart from sheltering important species of flora and fauna, such environmental patrimony has incomparable scenic beauty. PEPB has aroused the visitors' interest, because of the several natrual attractions (Vilani, \& Coelho, 2017). In addition, these fragments of the Atlantic Forest in Rio meet just the conditions we require for outside learning.

Environmental education can be defined as the processes through which the individual and the community construct social values, knowledge, skills, attitudes and skills aimed at conserving the environment for the common use of all as a contributor to a healthy and sustainable life. Environmental education should be based on dialog among different disciplines. Guided by the Política de Educação Ambiental, Lei n. 9.795, 1999 (Envi- 
ronmental Education Policy, Law n. 9,795, 1999), the proposal was to use elements of the natural space of this biome, the Brazilian Atlantic Forest, to learn about the morphophysiology of plants, relationships among species, coevolutionary and cultural processes in the use of plants in association with the conservation of environmental tracks in the Conservation Units of Rio. In this case, the track was applied as a pedagogical resource for teaching Botany. This research aimed to describe the teaching practice on the trail and change students' biased perceptions, as noted above.

\section{METHOD}

\section{1 Characterization of tracks}

This work was carried out with students in Biological Sciences classes at the Universidade Estadual da Zona Oeste (UEZO), as part of the botany curriculum, in Conservation Units of the Brazilian Atlantic Forest biome: Parque Nacional da Tijuca (Tijuca Forest Sector, entrance to Cascatinha Road, 850, Alto da Boa Vista, North Zone) and Parque Estadual da Pedra Branca (Piraquara Unit, West Zone) (Figure 1). The trails are open to the public. In class, botany students were given basic instructions on dress and field visits. The Parque Estadual da Pedra Branca (PEPB) -Piraquara Unit trail begins at the Barata Aqueduct (Figure 1A, 2.6-2.7) next to the headquarters and returns towards the source of the Piraquara River. PEPB maintains an extensive area of Secondary Dense Ombrophilous Forest (= Rain Forest), and it is considered the largest fragment of the Atlantic Forest located in the City of Rio de Janeiro, according to IBGE (Instituto Brasileiro de Geografia e Estatística). The Parque Nacional da Tijuca trail starts at the entrance of the Park by Afonso Viseu Square, via Estrada do Cascatinha, "Student Trail", passes through the "Cascatinha Taunay", and follows the trail to the Visitor Center - Barracão. This track is found in the Atlantic Domain of Dense Secondary Ombrophilous Forest. The paths in both tracks can be seen in Figure 1B. The trails are serviced by both park security and an environmental policing unit at the Piraquara Unit.

The class took place in an informal space and lasted for one day, starting at 9:30 a.m. and ending between 2:00 p.m. and 3:00 p.m., with stops for teacher-student interaction, learning and leisure time. Along the trail, a didactic sequence was developed with pre-established stops to study concepts, point out morphophysiological characteristics of the plants, examine ecological relationships, characterize the Atlantic Forest biome, and review social-environmental issues critically. The characterization of botanical, environmental, historical and social aspects was observed and described. Students were asked for their report after the field class as an evaluation activity. 
Figure 1

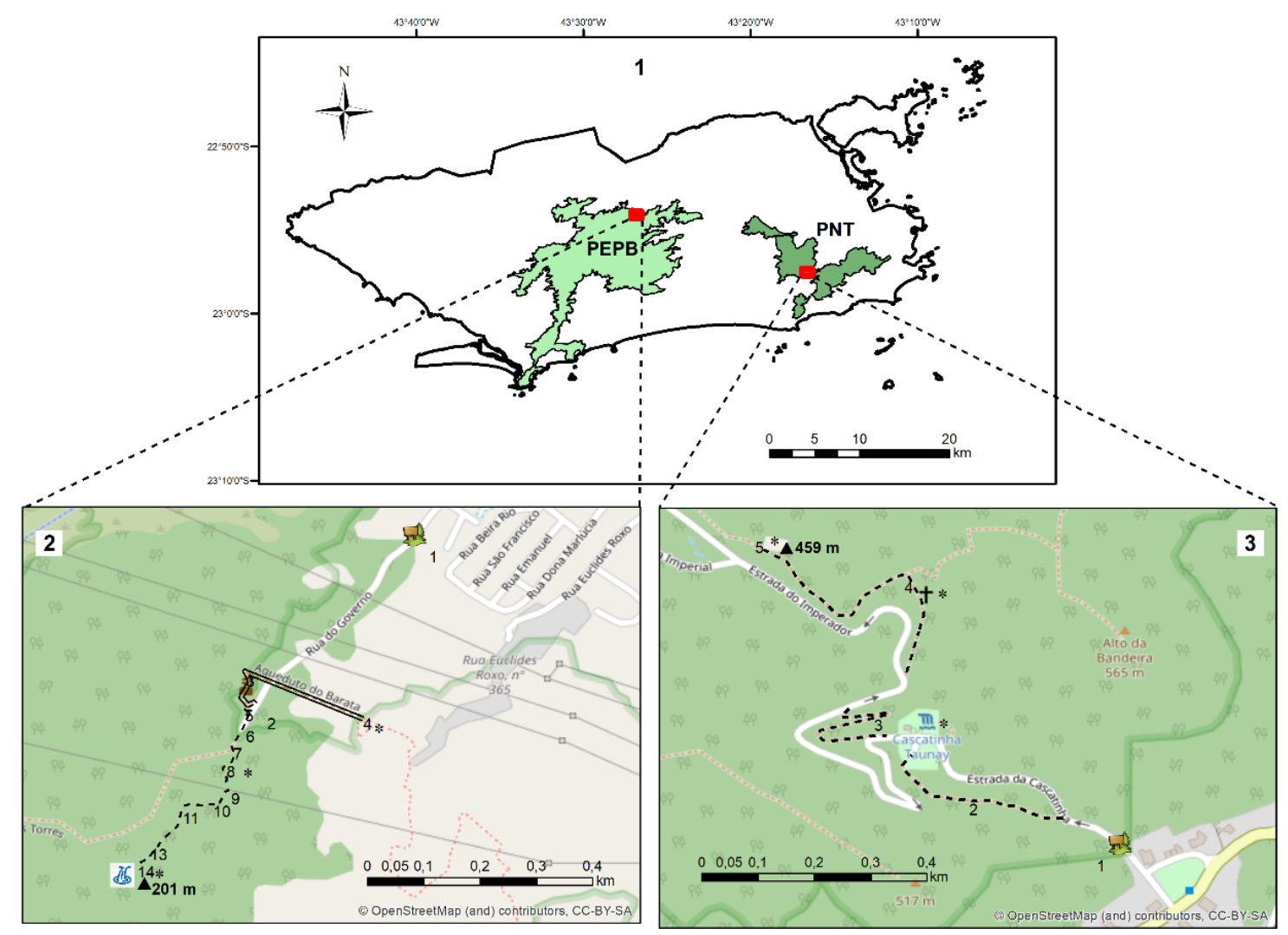

1. Map of Rio de Janeiro city. 2-3. Ecological trails in Conservation Units. 2. Parque Estadual da Pedra Branca (PEPB)Piraquara Unit: meet point (2), Barata Aqueduct where we can walk over (3-4), start point of trail and the first natural pool (5), expropriated houses in ruins (8), the second pool (10), the third pool (12), a small cave (13) wher we pass to go the water sources of Piraquara River finishing the trail (14). 3. Floresta Nacional da Tijuca (PNT): entrance of the Park (1), "Student Track”= Caminho da cascata (2). Then going through the "Cascatinha Taunay" and following trail - "Trilha dos bancos” (3) and trail

- "Caminho do Mesquita” (4) to the Visitor Center (5). *Indicates observation stops. Source: ArcMap 10.6 program.

\section{2 Perception of students}

Students' perceptions were evaluated after completing the Parque Estadual da Pedra Branca: Piraquara Unit trail walk. Data collection was done through the application of a questionnaire containing 13 mixed questions (objective and discursive) (Supplemental Information - SI), prepared and disseminated using the Google Forms virtual tool, in 2018 and 2019. The questions were answered by 20 students from a UEZO Botany class. Ethical aspects, such as confidentiality and anonymity, were considered. The data obtained were organized as descriptive and interpretative text, tables and graphs.

\section{RESULTS AND DISCUSSION}

\section{1 Characterization of tracks}

The trails pass through areas of closed Atlantic Forest. They can be considered from easy/light to moderate level, with stretches descending and rising, and lasting about 1 to 2 hours, route up to $3 \mathrm{~km}$, depending on the number of students and length of stops. These trails are favorable for teaching purposes. Regular stops are scheduled to observe the landscape, including watefalls, ponds, dams, and river banks. The Visitor Exhibit Center provides all the necessary environmental information (Figure 1B, 1C, 2.1). 
On the PEPB trail (Figure 2.2-2.13), it is also possible to bathe in the natural pool created by the secondary waterfalls of the Piraquara River (Figure 2.4). There are three natural pools along the trail. The trails in the Atlantic Forest are permeated by such water sources as wellsprings, rivers, waterfalls and natural pools, since this biome plays an important role in the maintenance of water resources. Both tracks have headquarters with educational exhibits and videos. During the course of walking the trail, we can observe plant diversity, both native and exotic. We can see plants with physical defenses, such as aculeus, trichomes, and thorns; different types of habits, such as herbaceous, shrub and arboreal; ecological relationships, such as epiphytism, as exemplified by Bromeliaceae and Orchidaceae, and mutualism can be seen in the embaúba plants (Cecropia sp.). Litter covers the substrate, making leaves visible at different stages of decomposition in the litter, as only foliar veins (Figure 2.11). It was possible to observe insects and other small- to medium-sized animals. It's worth pointing out that PEPB presents a high geodiversity and is comprised in its greater extension by the igneous-metamorphic complex denominated “Maciço da Pedra Branca” (Pereira, 2010).

The group heeded all rules regarding leaving footprints, bringing inset repellent, and carrying anti-allergenics. Both trails have the risk of slipping as a result of litter humidity and rains. Table 1 shows the aspects observed along the trail. Plants from the Atlantic Forest, Dense Secondary Ombrophilous Forest, are cataloged in different botanical surveys, making it possible to observe the taxonomic groups: Bryophyta, Pteridophyta, as for example the tree species Dicksonia sellowiana in the list of species threatened with extinction (Mallmann, Silva, Port, Oliveira, \& Schmitt, 2018), observed at Floresta da Tijuca, and families of Angiospermae (Magnoliophyta) - Bromeliaceae, Myrtaceae, Rubiaceae, Poaceae, Orchidaceae, Fabaceae (Leguminosae), Sapotaceae, Euphorbiaceae, Meliaceae, Melastomataceae, Urticaceae and Musaceae (Lima, Souza, Dittrich, \& Salino, 2012; Silva, Andreata, \& Guimarães, 2013; Solórzano, Guedes-Bruni, \& Oliveira, 2012; Stehmann, Forzza, Salino, Sobral, Costa, \& Kamino, 2009). Table 1 is based on the topics covered during the field lesson which lasted from two to three hours, considering both tracks.

Table 2 shows the features that caught the attention of students during the course, as well as the most interesting points. This table demonstrates the diversity of approaches taken on the field walk. 
Figure 2
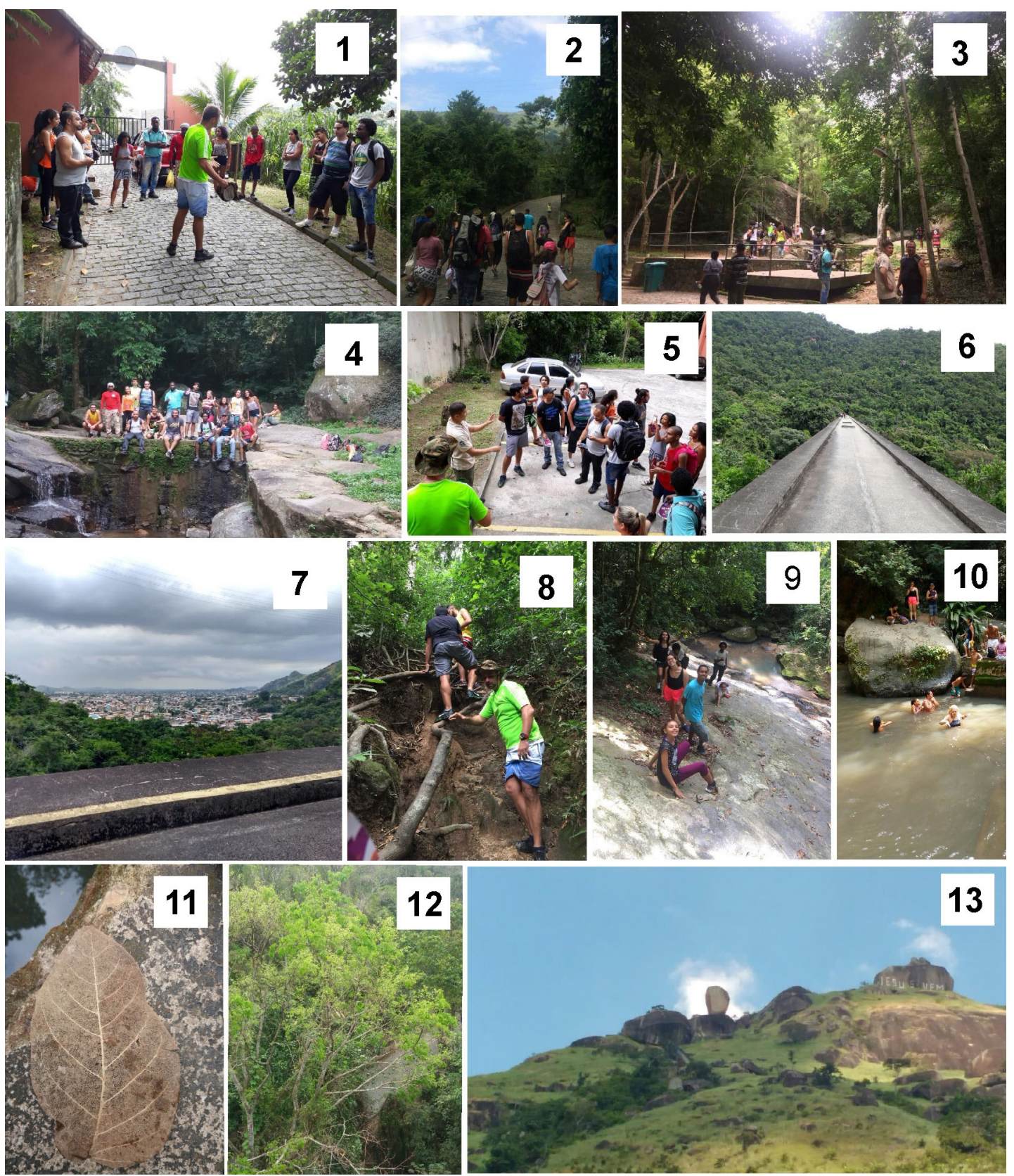

Track of the Piraquara Nucleus, Waterfalls circuit (trail map in Figure 1B): 1. Instruction to UEZO Biological Sciences students at the entrance of the Nucleus of Piraquara. 2. Group of visitors going towards the Visitor Center headquarters. 3. Deck of the most accessible natural pool of the Piraquara River (second waterfall). 4. Group of students at the last waterfall of the Piraquara River. 5. Instruction given

by INEA (Instituto Estadual do Ambiente) park security inside the Environmental Education Center before the visit to the Aqueduct. Apart from security, the aqueduct does not provide guardrails, and the risk of falling is present. 6. On the aqueduct inside the Núcleo da Piraquara. 7. View of the West Zone from the top of the Piraquara Aqueduct. 8. Excerpt from the trail where it is necessary to rest on the woody roots after the secondary falls toward the wellsprings. 9. Third pool of the trail in the Nucleus of Piraquara. 10. Group of students at the secondary falls of the Piraquara River. 11. Decomposed leaf litter; only the foliar veins can be observed. 12. Arboreal habit and epiphyte of the Atlantic Forest seen from above the aqueduct. 13. View of the Stone "Pedra Jesus Vem" (Jesus Come stone)

and "Pedra do Osso" (Stone of the Bone, from the headquarters of the Nucleus of Piraquara. Source: Personal observation. 
Table 1 - Ecological trail characterized from the point of view of botanical observation and consideration of plant-related environmental aspects.

\begin{tabular}{|c|c|c|}
\hline \multicolumn{3}{|c|}{ Characterization of the Ecological Trail } \\
\hline Botanic/Environment & Approaches & $\begin{array}{l}\text { Quantitative } \\
\text { evaluation* }\end{array}$ \\
\hline $\begin{array}{l}\text { Native and exotic species } \\
\text { (biodiversity) }\end{array}$ & $\begin{array}{c}\text { Bryophytes, Pteridophytes, and } \\
\text { Angiospermae famílies -Bromeliaceae, } \\
\text { Orchidaceae, Myrtaceae, Rubiaceae, } \\
\text { Fabaceae (Leguminosae), Urticaceae, } \\
\text { Musaceae, Panicum maximum } \\
\text { cv. Colonião** (Poaceae) }\end{array}$ & 1 \\
\hline Plant habits & $\begin{array}{c}\text { Herbaceous, shrub, arboreal, } \\
\text { lianas, epiphytic }\end{array}$ & 1 \\
\hline Litterfall & Different stages of decomposition & 2 \\
\hline Ecological relationship & $\begin{array}{c}\text { Epiphytic (orchids, bromeliads and } \\
\text { cacti), mutualism (domatia), herbivory }\end{array}$ & 2 \\
\hline Morphological adaptations & $\begin{array}{l}\text { Leaf form, flowers, stems, roots, } \\
\text { aculeus, thorns, trichomes, } \\
\text { variegation, phenotypic plasticity }\end{array}$ & 2 \\
\hline Plant physiology & $\begin{array}{l}\text { Photosynthesis, water absorption, } \\
\text { photomorphogenesis (quality and } \\
\text { quantity that penetrates the forest), } \\
\text { mineral nutrition, guttation }\end{array}$ & 3 \\
\hline Secondary metabolites & $\begin{array}{c}\text { Toxic plants, leaf color pigments, aromatic } \\
\text { substances: attraction and repellency }\end{array}$ & 2 \\
\hline
\end{tabular}

*Code of quantitative assessment based on the observation made in the field class: many (1), moderate (2) and few (3). **In the PEPB, the highest areas next to “Jesus Vem” stone are covered by this weed grass. 
Table 2 - Characterization of the ecological trail of Parque Estadual da Pedra Branca (PEPB): Piraquara Unit organized from the students' perspective. Answer to question 6 (SI).

\begin{tabular}{lll}
\hline \multicolumn{1}{c}{ Cited characters } & Quantitative evaluation* & (\%) Citation \\
\hline Biology & 2 & 34 \\
Reforestation area & 2 & 34 \\
Landscape & 4 & 68 \\
Plant diversity, flora & 2 & 34 \\
Animals of waterfall & & \\
\hline Environment & 3 & 51 \\
Spring of Piraquara River & 2 & 34 \\
Rock formation & 2 & 34 \\
View of the urban area from the & & \\
Mata & 2 & 34 \\
Geological History & 3 & 51 \\
Belvederes & 1 & 17 \\
Track, route & & \\
\hline
\end{tabular}

*Code of quantitative assessment based on the observation made in the field class: many (1), moderate (2) and few (3).

PEPB has a history of intense anthropogenic activity, mainly from the 18th century with the presence of countless sugarcane mills. We can also find historical richness associated with the extraction of firewood and use of charcoal in the forest by people who escaped slavery and settled there. While large structures were erected in the City of Rio de Janeiro, charcoal was needed for sharpening instruments at the forge for stone carving (Oliveira, 2004). Nowadays, we find remnants of quilombola populations within the PEPB: the community of Dona Bilina, Rio da Prata, Campo Grande district; the Camorim community, Jacarepaguá district; and the Astrogilda Cafundá community in the Jacarepaguá district (Lei n. 9.985, 2000 - Law n. 9,985, 2000). This facilitates the study of such topics as wood plants, culture, atmospheric pollution and greenhouse effect. Meanwhile, the history of Parque Nacional da Tijuca involves wide deforestation that began with coffee, followed by sugarcane monoculture, in the 18th century. Reflecting on this historic period leads us to consider the causes for the loss of native Atlantic Forest and, consequently, the importance of maintaining water resources, reforestation and natural regeneration (Freitas, Neves, \& Chernicharo, 2006). In 1861, D. Pedro II issued a document that instructed the planting of new seedlings with the coordination of Major Archer and the conservation of the forest that makes up the Floresta da Tijuca. The reforestation period lasted until 1874, and most of the seedlings used were transferred from the PEPB, which is considered "mother of the Tijuca forest" (Maya, 1966). Here both forests met.

Ecological, educational or interpretive trails are paths marked in natural areas that provide environmental interpretation, historical-cultural rescue and local phenomena (Silva, 2013). Ecological trails can be used to increase relevant knowledge, both contextual and real. Ecological trails play an important role in the process of environmental conservation; by making natural sites accessible, we often see a change in behavior toward natural resources and the man-nature relationship (Silva, 2013). Care should be taken in the proper use of flagged trails without shortening the route that results in negative impacts to the ecosystem.

For both formal and informal education, ecological trails are excellent spaces to practice environmental education programs, which must go beyond simply teaching content, but also propose changes in the way people think and evaluate their relationship with the environment (Campos; Filleto, 2011). It is contact with the natural ecosystem that motivates further interest in protecting the flora and fauna. We must find ways to achieve educational goals through practical experience. Teaching associated with visitation of an ecological trail allows all to observe the biodiversity, ecological relationships and external biological processes. While classroom coursework only involves didactic and theoretical subject, tracks allow students to gain three-dimensional knowledge through real-time outdoor programs. 


\section{2 Perception of Students}

To analyze students' perceptions, questions were devised, and anonymous responses were obtained through a virtual platform. The answers to the closed questions were organized in graphs (Figure 3A-E and Figure $4 \mathrm{~A}-\mathrm{B}$ ). The trail used was considered $100 \%$ owned and safe for undergraduate students, who felt satisfied and comfortable. The students considered that the use of ecological trails favors learning with an eclectic approach that includes biology, but also many other disciplines. The two-hour walk was sufficient for $75 \%$ of the students with some suggesting a longer time (Figure 3C). The students pointed out the effectiveness of multidisciplinary learning by addressing different areas of science, such as botany, animals, fungi, ecology, biodiversity, evolution, history, geography, water resources, conservation, and management practices in the Conservation Unit (Figure 3B, SI). It is worth emphasizing the importance of this pedagogical practice to promote the Conservation Unit, as well as the Atlantic Forest biome, encouraging environmental preservation measures and training professionals critical to solving environmental problems. About $75 \%$ of the students went to the PEPB for the first time, and only 25\% had visited another PEPB (Figure 3E).

Most students considered the lesson to have been well organized and complete and felt satisfied with the results (Figure 3A). One student pointed out the lack of written activity and record-keeping and photography of the trail during the class ride. Figure 3 shows the students' answers to the questions (SI) about the observations they made and those that drew the most attention.

Figure 3

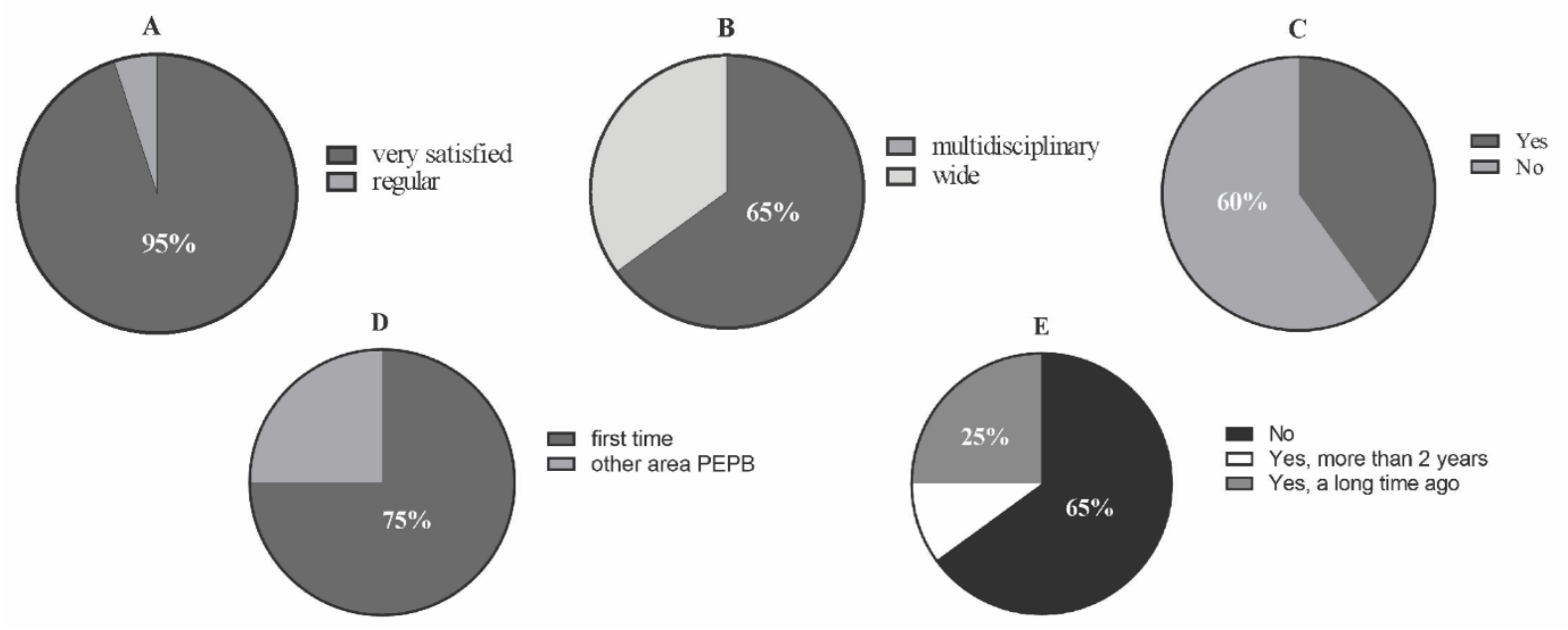

Graphs refer to closed-ended questions (SI 1) presented to UEZO students who participated in the field course on the ecological trail of the UC Parque Estadual da Pedra Branca: Piraquara Unit. A. Question 1. B. Question 5. C. Question 9 D. Question 11 10. Question 12.

Students pointed out different ecological relationships (Figure 4B), such as decomposition, plant and water, biodiversity, flora and fauna. Lazzari, Gonzatti, Scopel, \& Scur (2017) questioned 8th grade students from a public school in Rio Grande do Sul (RS) about the ecological functions of post-track plants in the Botanical Garden and they indicated photosynthesis, animal shelter and food, erosion, and water. 
Figure 4

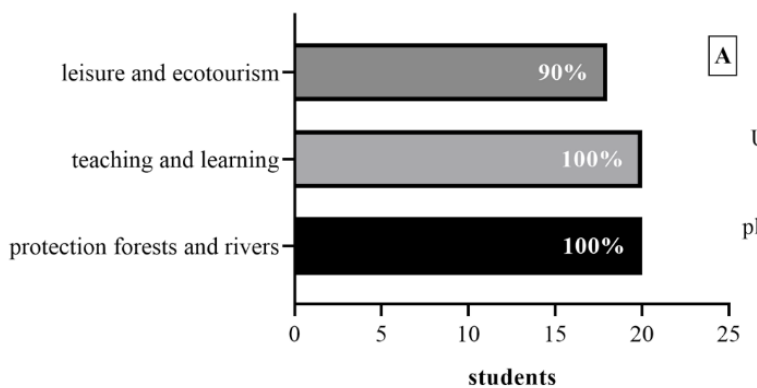

students

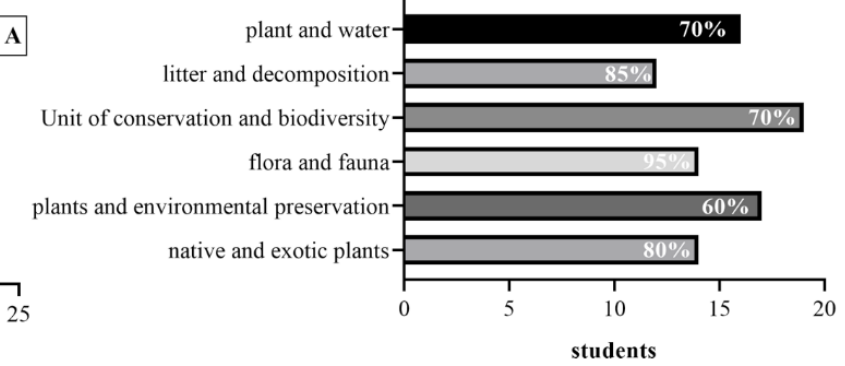

students

\begin{abstract}
The graphs refer to the open-ended questions (Supplement I) presented to the UEZO students who participated in the field lesson on the Ecological Trail of the Parque Estadual da Pedra Branca (PEPB): Piraquara Unit. A. Question 10: How do you see the Park? B. Question 13: What relationships were made on the trail?
\end{abstract}

Ecological trails are presented as a relevant instrument in the teaching-learning process, in particular the contextualization of these subjects and motivation of the students. The visit to the Conservation Unit (CU): Parque Nacional da Tijuca and Parque Estadual da Pedra Branca, as affirmed by the Sistema Nacional de Unidades de Conservação (SNUC), is an important conservation awareness strategy. The walking tours are multisensory experiences, and walking a trail in the ecosystem allows one to visualize the forest with its diversity of biota and feel the exhalation of secondary metabolites, listen natural sounds, feel the indument of the leaves by touch, and observe ecological relationships. According to Neris (2013) the playful aspect of practical activities, both in the laboratory and in nature, allows students to actively perform the experiments in a pleasurable way.

The Atlantic Forest, in particular, is considered one of the most important hotspots of the world biodiversity owing to its richness and its high level of endemism. It is quite threatened by anthropic action, which reinforces the use of this biome in the educational process, in order to reduce the negative impacts by increasing knowledge and understanding. The activities on the trail sharpened the environmental perception of the students and showed them the correlation between botany and environmental conservation. These trails provide an opportunity to explore effective and stimulative ways to promote the teaching of botany. Study in informal educational spaces favors the interaction and exchange of experiences and collaborating between teachers and students. Positive interaction among students and between students and teachers promotes learning. Trail walking is a good way to exit the theory of lab work and enter a practicum in which students can enjoy the interaction of flora and fauna in real time (Hershey, 2002; Kinoshita, Kinoshita, 2006; Silva, 2013)

\title{
4 CONCLUSION
}

For botany teaching, returning to nature has a positive effect on learning about plant life, including features such as morphology, physiology, chemistry, and ecological relationships, in addition to the rescue of human use of plants along history. This is the reverse of what some researchers call "botanical blindness" or a combination of "botanical neglect” and "zoocentrism” (Hershey, 2002; Silva, 2013; Salatino; Buckeridge, 2016). Our findings highlight the importance of natural trails as an integral part of teaching botany.

\section{ACKNOWLEDGEMENTS}

To Unit of Conservation: Parque Nacional da Tijuca, Sector Forest and Parque Estadual da Pedra Branca, Piraquara Unit and their park ward service of Instituto Estadual do Ambiente (INEA). Also, we thank to Prof. Alexandre P. Esperanço for the help in using Google Forms. 


\section{REFERENCES}

Campos, R. F., \& Filleto, F. (2011). Análise do perfil, da percepção ambiental e da qualidade da experiência dos visitantes da Serra do Cipó (MG). Revista Brasileira de Ecoturismo 4, 69-94.

Carvalho, J., \& Bóçon, R. (2004). Planejamento do traçado de uma trilha interpretativa através da caracterização florística. Revista Floresta, 34, 23-32.

Firme, R. P., Vincenz, R. S., Macedo, G. V., Silva, I. M., \& Oliveira, R. R. (2001). Estrutura da vegetação de um trecho de Mata Atlântica sobre solos rasos (Maciço da Pedra Branca, RJ.) Eugeniana, 25, 3-10.

Freitas, S. R., Neves, C. L., \& Chernicharo, P. (2006). Tijuca National Park: two pioneering restorationist initiatives in Atlantic Forest in southeastern. Brazilian Journal of Biology, 66(4), 975-982.

Hershey, D. (2002). Plant blindness: we have met the enemy and he is us. Plant Science Bulletin, 48, 78-84.

INEA - Instituto Estadual do Ambiente. (2013). Trilhas: Parque Estadual da Pedra Branca. Rio de Janeiro: INEA.

Kinoshita, L. S., \& Kinoshita, L. S. (2006). A Botânica no Ensino Básico: relatos de uma experiência transformadora. $1^{\circ}$ Edição. São Carlos: RiMa.

Lazzari, G., Gonzatti, F., Maria Scopel, J. M., \& Scur, L. (2017). Trilha ecológica: um recurso pedagógico no ensino da Botânica. Scientia cum Industria, 5(3), 161-167.

Lei n. 9.795, de 27 de abril de 1999 (1999). Dispõe sobre a educação ambiental, institui a Política Nacional de Educação Ambiental e dá outras providências. Diário Oficial da União. Brasília, DF.

Lei n. 9.985, de 18 de julho de 2000 (2000). Ministério do Meio Ambiente. Regulamenta o art. 225, § 1º, incisos I, II, III e VII da Constituição Federal, institui o Sistema Nacional de Unidades de Conservação da Natureza e dá outras providências. Diário Oficial da União. Brasília, DF.

Lima, R. A. F., de Souza, V. C., Dittrich, V. A. O., \& Salino, A. (2012). Composição, diversidade e distribuição geográfica de plantas vasculares de uma Floresta Ombrófila Densa Atlântica do Sudeste do Brasil. Biota Neotropica, 12(1), 241-249.

Mallmann, I. T., Silva, V. L., Port, R. K., Oliveira, F. B., \& Schmitt, J. L. (2019). Spatial distribution analysis of Dicksonia sellowiana Hook. in Araucaria forest fragments with different sizes. Brazilian Journal of Biology, 7(2), 337-344.

Maya, R. O. C. (1966). A Floresta da Tijuca. Rio de Janeiro: Editora Bloch.

MMA - Ministério do Meio Ambiente. (2006). Diretrizes para Visitação em Unidades de Conservação. Secretaria de Biodiversidade e Florestas. Brasília: Diretoria de Áreas Protegidas.

Neris, D. (2013). A importância das aulas práticas no ensino de botânica. Recuperado de http://biopedagogia. webnode.com.br/news/a-import\%C3\%A2ncia-de-aulas-praticas--no-ensino-de-bot\%C3\%A2nica/.

Oliveira, R. R. (2004). As marcas do Homem na Flores: História Ambiental de um trecho de Mata Atlântica. Rio de Janeiro: Editora PUC.

Pereira, E. S. (2010). Geodiversidade do Parque Estadual da Pedra Branca-RJ: subsídios para o planejamento geoturístico. (Dissertação de Mestrado em Geologia). Instituto de Geociências, da Universidade Federal do Rio de Janeiro, UFRJ, Rio de Janeiro. 
Salatino, A., \& Buckeridge, M. (2016). “Mas de que te serve saber botânica?” Estudos Avançados, 30(87), 17796.

Silva, M. F. O., Andreata, R. H. P., \& Guimarães, P. J. F. (2013). Melastomataceae no Parque Estadual da Pedra Branca, Rio de Janeiro, RJ, Brasil. Hoehnea, 40(4), 679-700.

Silva, J. R. S. (2013). Concepções dos professores de Botânica sobre ensino e formação dos professores. (Doutorada em Ciências, Botânica). Universidade de São Paulo, São Paulo.

Stehmann, J. R., Forzza, R. C., Salino, A., Sobral, M., Costa, D. P., \& Kamino, L. H. Y. (2009). Plantas da Floresta Atlântica. Rio de Janeiro: Jardim Botânico do Rio de Janeiro.

Solórzano, A., Guedes-Bruni, R. R., \& Oliveira, R. R. (2012). Flower composition and structure of na Atlantic Rain Forest Tract, with land use history of banana plantation at the Pedra Branca State Park, Rio de Janeiro, Brazil. Revista Árvore, 36(3), 451-462.

Ursi, S., Barbosa, P. P., Sano, P. T., \& Berchez, F. A. S. (2018). Ensino de Botânica: conhecimento e encantamento na educação científica. Estudos Avançados, 32(94), 7-24.

Vilani, R. M., \& Coelho, B. S. (2017). Ecoturismo no Parque Estadual da Pedra Branca, Rio de Janeiro, Brasil. Revista Turismo \& Desenvolvimento, 27/28, 535-546. 


\section{ANEXO A}

\section{SUPPLEMENTAL INFORMATION}

\section{Questionnaire}

For questions from 1 to 4 consider 0 (no/none), 1 (few), 2 (yes, good), 3 (yes, excellent).

1. What is the degree of satisfaction and learning after your class ride (track)?

0() 1() $2($ ) $3($ )

2. Do you think that informal spaces (track / park) favor learning?

0() $1($ ) $2($ ) $3($ )

3. Did you feel comfortable taking the class (track)?

0() $1($ ) $2($ )

If you checked option 1 , indicate the reason

4. Did you consider the track safe and proper as a class exercise?

0() $1($ ) $2($ ) $3($ )

5. How would you classify your learning after using the trail as a resource?

( ) restrict; to only one area of knowledge

( ) wide; take up various topics of biology

( ) multidisciplinary, approach different areas, not just biology

6. What did you see and what did you like about your visit to the park?

7. Did anything bother you or was something missed in your class at the Piraquara Unit?

8. After the visit, was anything not covered in your visit to the Park (CU)?

9. Do you think we should extend the visiting time for additional questions?

( ) Yes ( ) No

10. How do you see the Park? (you can check more than one topic)

( ) protection of forests and rivers

( ) teaching and learning

( ) place to be exploited economically by man

( ) as a problem

( ) leisure and ecotourism

( ) other

11. How many times have you come to the Parque Estadual da Pedra Branca (PEPB)?

( ) First time ( ) 2 to 5 times ( ) several times ( ) I went to another area PEPB

12. Did you know of the existence of the state park before this visit?

( ) Yes, a long time ago ( ) Yes, more than 2 years ( ) No 
13. What relationships were observed on the trail? (Check as many options as necessary.)

( ) Plant and water

( ) Litter and decomposition

( ) Conservation Unit and biodiversity

( ) Flora and fauna

( ) Plants and environmental preservation

( ) Native and exotic plants

( ) Other 